\title{
Saudi Arabian Tertiary Teachers' and Learners' Attitude towards the Communicative Language Teaching (CLT)
}

\author{
Marwan Abdulrazzaq Albahri, Ping Yang, and Mohamed Moustakim
}

\begin{abstract}
Research indicates Communicative Language Teaching (CLT) helps to acquire written and spoken English. However, an investigation of Saudi teachers' and students' attitudes toward the CLT approach is required. This study aims to discuss students' and teachers' attitude of various aspects of Communicative Language Teaching (CLT) in Saudi Arabia. The emphasis lies on behavioral beliefs and culture on attitude towards CLT approach. This study will lead to a clearer understanding of the suitability of the CLT approach and will lead to further investigation on factors that could make the approach more suitable in the context of Saudi Arabia.
\end{abstract}

Index Terms-Attitude, communicative language teaching, culture, EFL, Saudi Arabia.

\section{INTRODUCTION}

English has become a requirement for active interaction in the world of today [1]. Saudi Arabia is not an exception. English language has become the medium of instructions in Saudi tertiary educational institutions for both English major and non-English major courses. Thus, English proficiency is a requirement for admission to university degrees and programs [2]. English language instruction in Saudi Arabia works to meet particular interests of the Saudi Ministry of Education [3]. These interests include developing learners listening, speaking, reading and writing skills so that they are able to communicate effectively with English speakers and with the other language speakers [4]. Tertiary institutions in Saudi Arabia also offer foundation English courses as part of their curriculum. However, these courses are not sufficient to support students to effectively manage discipline-oriented courses at the university level [5]. In addition, Saudi learners' overall English proficiency level is not yet satisfactory [6], [7].

Researchers show that teaching methodologies implemented in Saudi Arabia do not meet the desired goals, particularly for teaching English as a foreign language (EFL). According to Alrashidi and Phan [8] one of the main reasons for Saudi students' low proficiency is the dependence on outdated teaching methodologies that supports a teacher-centered ideology. These methodologies make learners passive and rely on memorization as a learning

Manuscript received June 15, 2017; revised September 14, 2017. This work is part of $\mathrm{PhD}$ work and financially supported by the Saudi Cultural Mission Scholarship.

M. A. Albahri is with the Western Sydney University, Australia (18195053@student.westernsydney.edu.au).

P. Yang and M. Moustakim are with the School of Humanities and Communication Arts, Western Sydney University (P.Yang@westernsydney.edu.au, M.Moustakim@westernsydney.edu.au). strategy only. This teacher-cantered style of instruction is opposite to learner-centred pedagogy, and contributes little to the learner-centred learning environment [9]. Saudi culture traditionally highlights values that strongly dictate the role of a teacher in the learning process [9]. Therefore, teachers are viewed as the authority in the classroom and as experts who impart their knowledge to students. In turn, students do not have clear roles to act; they are just knowledge receptors that poorly absorb teachers' instructions. On the other hand the CLT approach promotes authentic communication, meaningful interactions, discussions, pair and group work, etc. Thus, CLT approach to language teaching may come into conflict with the particular elements of Saudi's cultural practice where a formal relationship between the student and teacher is one-way dominant. Importantly, it is expected that the loosely structured nature of CLT approach may encounter resistance from teachers who believe in a more rigidly structured curriculum. For example, a study conducted outside Saudi Arabia has identified culture-based resistance to CLT by teachers and students accounting for their effect on its adoption in classrooms [10]. Even though the adoption of a learner-centred teaching style such as the CLT approach for English language classes in Saudi Arabia may boost the English learners' performance in tertiary level, an investigation of teachers' and students' attitudes toward the CLT approach is meaningful. In fact, a teaching methodology and its associated components are more likely to be implemented if it is viewed favorably by teachers and students [11].

This study is an attempt to measure the attitudes of students and teachers toward the CLT approach, relate their attitudes to their educational background and to identify the main barriers and opportunities of the CLT implementation within Saudi educational institutions. The purpose of the study is to investigate both Saudi tertiary teachers' and students' attitudes toward the CLT as a teaching approach. The study will also investigate the relationship of teachers' and students' attitudes with regards to their educational background and their previous exposure to CLT approach. Moreover, the study will determine the factors that motivate or hinder the implementation of the CLT approach in English language classrooms from teachers and students point of view. Identifying barriers and opportunities in both target groups with the aim of having a better understanding of how to implement CLT programs in the future in an effective manner. Specifically, this study is important to understand whether persistent under-achievement by Saudi students in English language learning is the result of the inadequate implementation of, and resistance to, modern language instruction methodology [12]. 


\section{LITERATURE REVIEW}

This study of Saudi tertiary teachers' and students' attitudes toward the implementation of CLT methods in Saudi Arabia is rooted in three areas of the literature: (a) current ELT practices in Saudi Arabia; (b) CLT Approach in ESL and EFL contexts; and (c) teachers' and learners' attitudes toward CLT.

\section{A. Current ELT Practices in Saudi Arabia}

Teaching the English language in Saudi Arabia has received great attention from the Saudi Ministry of Education. It has implemented the English language as an obligatory unit for all levels starting from the primary schools to universities [7]. The aims of teaching English as a foreign language in Saudi Arabia are stated in the Saudi policy of education article number 50 of the Saudi Arabian education policy which are "Furnishing the students with at least one of the living languages, in addition to their original language, to enable them to acquire knowledge and sciences from other communities and to participate in the service of Islam and humanity" [3]. The Saudi Ministry of Education stated that the goal of English language teaching is developing learners' communicative competence to communicate with English speaking persons [4]. However, despite the above mentioned communicative goal, efforts and publications which support the communicative teaching method Liton [4], [13], Fareh [14], Khan [12] ,Rahman and Alhaisoni [7] and Rajab [15] argue that English teaching in Saudi Arabia has not yet met its goals. They have identified various reasons such as the use of traditional teaching methods, teachers' role in class, students' role, teachers' preparation, etc.

The main reason behind the low achievement in English proficiency level among Saudi learners is the teachers' use of traditional teaching methods such as the Grammar Translation method and the Audi-lingual method. According to Fareh [14] the main challenge of teaching English causing inadequately prepared students in the Arab world is use of inadequate teaching methodology. The issue of reliance on traditional method has also been pointed out by Al-Johani [13]. Al-Johani states that students' participation is never encouraged and lesson content is generally delivered to students in a form of a lecture. In an investigation of English learning difficulties in the Saudi context by Khan, the issue of teaching methodology was considered as the major reason behind students' low achievement [12]. Teacher role is an essential element in the language teaching process. Another reason as pointed out repeatedly by studies is that the Saudi context contributes to the low competence of Saudi learners. EFL teachers in Saudi Arabia have a dominant position; they talk most of the time while learners are mostly silent [13]. According to Almutairi [16] "The teaching atmosphere in classes in Saudi Arabia reflects the traditional practice. The teacher spends a lot of time explaining and illustrating new language items and writing on the board, while the students sit and listen, read, or copy". The above reasons causing the low learners' competency level assure the urgent need for proper implementation of the CLT approach in the Saudi context to meet the Ministry of Education goals in the Saudi context.

\section{B. CLT Approach in ESL and EFL Context}

Communicative language teaching (CLT) is widely acknowledged as an approach to language teaching that acknowledgeds the main function or purpose of language use as communication. The main goal of CLT is therefore to facilitate the development of the learner's communicative competence [17]. On the basis of this main goal, CLT aims is to place the L2 learner in real-life situations that require communication in L2 [17]. As described by Richards [18], CLT is based upon the functional view of language which holds that language is a vehicle for the expression of functional meaning and emphasizes the pragmatic and communicative dimension rather than merely the grammatical characteristics of language. Describing CLT in this way, there is clearly an emphasis placed on communicative competence emerging from the learner's production of the target language [19]. As such, there is still importance given to the learner's grammar and vocabulary knowledge (linguistic competence); ability to utter statements appropriate to particular social situations (sociolinguistic competence); ability to manage a conversation (discourse competence); and the ability to repair communication breakdowns (strategic competence) [19].

Since first introduced during the 1970s, the CLT approach has gradually overtaken other traditional methods of language teaching, primarily because "the centrality of grammar in language teaching and learning was questioned" [20]. Today, major works on language instructions by Harmer [21], Richards and Rodgers [22], and Brown [23] all contain major sections on the CLT approach. Notably, the increased research focus on English language instructions has also resulted in increased professionalism among English language teachers [24]. The language learning is best apprehended in CLT [23]. Due to perceived deficiencies in the traditional teaching methods, CLT gives consideration to learners' needs to use the second language to communicate. As such, CLT denotes a revolution in the language teaching focus. In term of its principles, CLT is not a list of strict teaching methods, CLT is recognized as an approach rather than a method [23]. A method is considered by a finite set of described rules concerning linguistic structures. An approach is dynamic and subject to amendments based on teachers' experiences or student learning in the classroom [23].

Although the communicative approach has been widely adopted, it has come under criticism from some scholars in recent years. These scholars argue that even though the communicative approach serves a useful function in correcting shortcomings in traditional approaches, it ignores the importance of the learning context, including the culture of the teachers and students involved in the language instruction [25]. However, such criticisms focus on the chauvinistic attitudes of CLT proponents rather than on the sources of resistance to the CLT approach. Other critics of CLT argue that the theoretical focus on interaction is rarely implemented and that even though many classrooms have the form of being communicative, the functional elements remain largely grammatically focused [26], [27]. 


\section{Teacher's and Learner's Attitude toward CLT}

Recent attempts to implement CLT in EFL context have provoked a great deal of research efforts. While some researchers have focused on the need for the CLT, others have investigated the suitability of the CLT approach for a specific cultural context. Investigating teachers' and students' attitude is an essential factor in determining teachers' and learners' intention and behaviour with respect to a learning approach in classrooms. Existing research on teachers' attitudes toward the CLT approach has been mainly conducted in the Asian and European contexts [10], [28]-[33] Ansarey [30] stated that despite teachers' strong desire to implement the CLT approach, teachers are not confident about implementing the CLT approach fully.

A few studies suggest a positive students' attitude towards the CLT approach [34]. In Vietnam an investigation of students' attitude towards the CLT approach shows that students held positive attitude toward the CLT approach [35]. Also positive students attitude toward the CLT approach is suggested among the first year university students in Taiwan, especially those who started learning English at a younger age [36]. This positive attitude of students toward the CLT approach is also shared by the Arab learners. In Jordan an investigation towards learners attitude towards CLT approach shows positive attitude toward the CLT approach [37].

Although the above cited studies show that EFL countries have shifted toward the CLT approach as a favourable teaching approach for their nations to develop learners communicative competence, empirical studies show a gap between desired teaching approach and actual classroom practices [28]-[30], [34], [37]-[39]. While some scholars such as Holliday argue that resistance to a specific teaching method is due to cultural and contextual differences [40], others claim that the CLT approach should be replaced by a contextual approach since CLT ignores the context that is a vital aspect of language teaching [25]. Thus, investigating teachers' and learners' attitude is an essential factor in determining teachers' and learners' intention and behaviour with respect to a learning approach in classrooms. The teaching methodology is more likely to be implemented if teachers view it favourably and consider the students' needs [11]. Such an investigation of both Saudi teachers' and learners' attitudes will defiantly disclose their thoughts, barriers, opportunity and intention to practice CLT in Saudi Arabia.

\section{THEORETICAL BACKGROUND AND FRAMEWORK}

Two major theories will be used to support this research arguments namely the theory of planned behavior (TPB) developed by Icek Ajzen (1988) and the cultural variability theory developed by Hofstede (1981). TPB, Icek Ajzen (1988) presents a framework for measuring how human actions are shaped. As such, TPB aims to predict the manifestation of a particular behaviour on the condition that the behaviour is intentional [41]. The underlying assumptions in the TPB are that 'human beings usually behave in a sensible manner; that they take account of available information and implicitly or explicitly consider the implications of their actions' [42]. On the basis of this assumption, the person's intention to perform or not perform an action is positioned as the most important immediate driver of that action [42]. Thus, the key construct in the TPB is human intention [42].

Culture is typically described as the prevailing values, principles, ritual, beliefs, and ethics shared among an identifiable group of people (Jackson, \& Hogg, 2010). Arguably, the most recognised framework for identifying cultural variability is the 'Cultural Dimensions' model developed by Geert Hofstede [43]. Importantly, the underlying assumption in Hofstede's framework is that individuals and groups organise their thoughts, emotions, and behaviours in relation to their environment (Alkailani, Azzam \& Athamneh, 2012). The proposed research aims to investigate Saudi tertiary language teachers' and students' attitudes towards CLT, the relationship of teachers' and students' attitude with their educational background and factors that enable or constrain the implementation of the CLT approach. As a result, it is important to determine the extent to which cultural forces are at work in shaping these attitudes toward the CLT approach. To achieve this outcome, two dimensions of Hofstede's cultural variability framework will be applied namely power distance dimention and individualism collectivism dimension to support this research investigation. Fig. 1 shows the model.

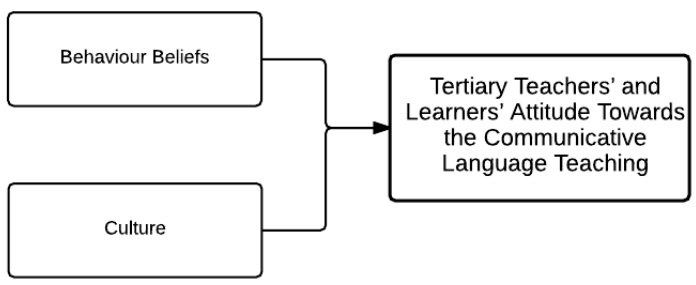

Fig. 1. Research model.

\section{HYPOTHESIS DEVELOPMENT}

Fishbein and Ajzen [44] defined attitude as a 'learned predisposition to respond in a consistently favourable or unfavourable manner with respect to a given object' (p. 6). In terms of the TPB, attitude is conceptualised as to the person's 'positive or negative evaluation of performing the particular behaviour of interest' [42]. Underpinning a person's attitudes are his or her 'beliefs about the consequences of performing the behaviour multiplied by evaluations of those consequences' [41]. The rationale for applying the TPB framework to a study of teachers' and students' attitudes towards CLT is that it is arguably 'the most influential theory for the prediction of social... behaviour' [41]. The TPB framework states that a person's behaviour is predicted by his/her behavioural intention, which is influenced by his/her attitude toward the behaviour, among other factors [45]. Based on the TPB a person behavioural beliefs shape the person's attitude toward an object.

Regarding the cultural variable, Scarino [46] asserts that learning and communication are social and interactive. Certainly, the contrasting profiles of CLT and grammar translation method provided above point to the higher level of social interaction for communicative purposes required of L2 learners when being taught according to the CLT 
approach. This emphasis on teacher-student and student-student interaction in the CLT classroom however draws attention to the influence of socio-cultural factors on language learning processes and outcomes. In turn, evidence is available that demonstrates how different cultural norms, values and customs may influence the nature of the teacher-student relationship in the classroom as well as the preferred teaching and learning methods embedded in the subject curriculum [47]. Therefore, we hypothesize,

H1: Behavioral beliefs have a positive impact on tertiary teachers' and learners' attitude towards the communicative language teaching in Saudi Arabia.

H2: Culture has a positive impact on tertiary teachers' and learners' attitude towards the communicative language teaching in Saudi Arabia.

\section{Methodology}

The proposed study will apply a mixed-methods research design, using qualitative and quantitative methods to collect data [48]. The first phase collects the quantitative data determining teachers and students' attitude scales, frequencies and relationships of responses. The second phase includes the qualitative data collection and analysis seeking to explain and support outcomes obtained from the quantitative process. Previous validated measures will be used. For example, the teachers' attitude scale is adapted from Karavas-Doukas (1996), and the students' attitude scale is adapted from Savignon and Wang (2003). Quantitative data will be analysed using the SPSS software. Interview transcriptions will be codified and analysed through thematic analysis using the NVIVO Software.

\section{CONCLUSION AND FUtURE WORK}

Arguably, citizens learning a foreign language in educational institutions are of great importance to any nation as individuals who speak more than a language will be more diversified and flexible to communicate, interact, and learn across different cultural contexts. This research will add to the existing knowledge related to teachers' and students' attitudes toward CLT approach in the Saudi cultural context. The results of this study will be beneficial to the Saudi Ministry of Education as well as the nation's tertiary institutions and can be used to guide policy formulation on English language teaching in the country. Therefore, its findings will make a valuable contribution to helping the targeted teachers and students understand that CLT could be used as a pedagogical approach to the English language instruction in Saudi context. Secondly, the proposed research will identify and assess the factors that promote and hinder CLT adoption in Saudi Arabia. Thirdly, the findings of the study may work as guidelines for future decisions pertaining the implementation of the CLT approach in Saudi Arabia.

\section{REFERENCES}

[1] A. Klimczak-Pawlak, "Towards the pragmatic core of English for European communication: The speech act of apologising in selected Euro-Englishes," 2014.
[2] A. M. Al-Asmari and M. Khan, "World Englishes in the EFL teaching in Saudi Arabia," Arab World English Journal, vol. 5, no. 1, pp. 316-325, 2014.

[3] D. T. A. Hajailan, Teaching English in Saudi Arabia, Riyadh: Aldar Alsawlatiah, 2003

[4] H. A. Liton, "Developing EFL teaching and learning practices in Saudi colleges: A review," International Journal of Instruction, vol. 5, no. 2, pp. 129-152, 2012

[5] H. A. Liton, "EFL teachers' perceptions, evaluations and expectations about English language courses as EFL in Saudi universities," vol. 6, no. 2, pp. 19-34, 2013

[6] A. M. Ahmad, "Kumaravadivelu's framework as a basis for improving English language teaching in Saudi Arabia: Opportunities and challenges," English Language Teaching, vol. 7, no. 4, pp. 96-110, 2014.

[7] M. M. Rahman and E. Alhaisoni, "Teaching English in Saudi Arabia: Prospects and challenges," Academic Research International, vol. 4, no. 1, pp. 112-118, 2013

[8] O. Alrashidi and H. Phan, "Education context and English teaching and learning in the Kingdom of Saudi Arabia: An overview," English Language Teaching, vol. 8, no. 5, pp. 33-44, May 2015

[9] A. Mahboob and T. Elyas, "English in the Kingdom of Saudi Arabia," World Englishes, vol. 33, no. 1, pp. 128-142, 2014.

[10] G. Hu, "Potential cultural resistance to pedagogical imports: The case of communicative language teaching in China," Language Culture and Curriculum, vol. 15, no. 2, pp. 93-105, 2002.

[11] Y. K. Türel and T. E. Johnson, "Teachers' belief and use of interactive whiteboards for teaching and learning," Journal of Educational Technology \& Society, vol. 15, no. 1, pp. 381-394, 2012.

[12] I. A. Khan, "Learning difficulties in English: Diagnosis and pedagogy in Saudi Arabia," Educational Research, vol. 2, no. 7, pp. 1248-1257, 2011.

[13] H. M. Al-Johani, "Finding a way forward: The impact of teachers' strategies, beliefs and knowledge on teaching English as a foreign language in Saudi Arabia," Doctoral thesis, 2009.

[14] S. Fareh, "Challenges of teaching English in the Arab world: Why can't EFL programs deliver as expected?" Procedia-Social and Behavioral Sciences, vol. 2, no. 2, pp. 3600-3604, 2010.

[15] H. Rajab, "Developing speaking and writing skills of L1 Arabic EFL learners through teaching of IPA phonetic codes," Theory and Practice in Language Studies, vol. 3, no. 4, pp. 653-659, 2013.

[16] N. H. Almutairi, "The influence of educational and sociocultural factors on the learning styles and strategies of female students in Saudi Arabia," Doctoral thesis, University of Leicester, United Kingdom, 2008.

[17] S.-C. Chang, "A contrastive study of grammar translation method and communicative approach in teaching English grammar," English Language Teaching, vol. 4, no. 2, pp. 13-24, 2011.

[18] J. C. Richards, Approaches and Methods in Language Teaching: A Description and Analysis, Cambridge; New York: Cambridge University Press, 1986.

[19] K. Brandl, Communicative Language Teaching in Action: Putting Principles to Work, Upper Saddle River, NJ: Pearson Prentice Hall, 2008.

[20] J. C. Richards, Communicative Language Teaching Today, New York: Cambridge University Press., 2006

[21] J. Harmer, The Practice of English Language Teaching, 5th ed., Harlow, England: Pearson Education, 2015.

[22] J. C. Richards, and T. S. Rodgers, Approaches and Methods in Language Teaching, 2nd. ed., New York: Cambridge University Press, 2001.

[23] H. D. Brown, Teaching by Principles: An Interactive Approach to Language Pedagogy, 4rd ed., White Plains, NY: Pearson Education, 2015.

[24] J. C. Richards, "Second language teacher education today," RELC, vol 39, no. 2, pp. 158-177, 2008.

[25] S. Bax, "The end of CLT: A context approach to language teaching," English Language Teaching Journal, vol. 57, no. 3, pp. 278-287, 2003

[26] E. Gatbonton and N. Segalowitz, "Rethinking communicative language teaching: A focus on access to fluency," The Canadian Modern Language Review, vol. 61, no. 3, pp. 325-353, Mar 2005, 2014-05-18, 2005.

[27] B. Kumaravadivelu, Understanding Language Teaching: From Method to Postmethod, Mahwah, N.J.: Lawrence Erlbaum Associates, 2006.

[28] D. Nunan, "The impact of English as a global language on educational policies and practices in the Asia-Pacific region," TESOL Quarterly, vol. 37, no. 4, pp. 589-613, 2003. 
[29] W. Littlewood, "Communicative and task-based language teaching in East Asian classrooms," Language Teaching, vol. 40, no. 3, pp. 243-249, 2007.

[30] D. Ansarey, "Communicative language teaching in EFL contexts: Teachers attitude and perception in Bangladesh," ASA University Review, vol. 6, no. 1, pp. 61-78, 2012.

[31] E. Karavas-Doukas, "Using attitude scales to investigate teachers' attitudes to the communicative approach," English Language Teaching Journal, vol. 50, no. 3, pp. 187-198, 1996.

[32] M. Chang, "Taiwanese college English teachers' attitudes toward communicative language teaching," Taiwanese College English Teachers' Attitudes toward Communicative Language Teaching, 2009.

[33] S. M. Mustapha and R. A. Yahaya, "Communicative language teaching (CLT) in Malaysian context: Its' implementation in selected community colleges," Procedia-Social and Behavioral Sciences, vol. 90, pp. 788-794, 2013.

[34] I. F. Chung and H. Yi-Cheng, "The implementation of communicative language teaching: An investigation of students' viewpoints,' Asia-Pacific Education Researcher (De La Salle University Manila), vol. 18 , no. 1 , pp. 67-78, 2009.

[35] K. Ngoc and N. Iwashita, "A comparison of learners' and teachers' attitudes toward communicative language teaching at two universities in Vietnam," University of Sydney Papers in TESOL, vol. 7, pp. 25-49, 2012.

[36] S. J. Savignon and C. Wang, "Communicative language teaching in EFL contexts: Learner attitudes and perceptions," IRAL, International Review of Applied Linguistics in Language Teaching, vol. 41, no. 3, pp. 223-249, 2003.

[37] S. M. Asassfeh, F. M. Khwaileh, Y. M. Al-Shaboul, and S. S. Alshboul, "Communicative language teaching in an EFL context: Learners" attitudes and perceived implementation," Journal of Language Teaching \& Research, vol. 3, no. 3, pp. 525-535, 2012.

[38] D. A. Bruner, K. Sinwongsuwat, and B. Radic-Bojanic, "EFL ora communication teaching practices: A close look at university teachers and A2 students' perspectives in Thailand and a critical eye from Serbia," English Language Teaching, vol. 8, no. 1, pp. 11-20, Jan 2015

[39] K. M. R. Karim, “Teachers' perceptions, attitudes and expectations about communicative language teaching (CLT) in post-secondary education in Bangladesh," 2004.

[40] A. Holliday, Appropriate Methodology and Social Context, Cambridge: Cambridge University Press, 1994.

[41] A. Rivis and P. Sheeran, "Descriptive norms as an additional predictor in the theory of planned behaviour: A meta-analysis," Current Psychology, vol. 22, no. 3, pp. 218-233, 2003.

[42] I. Ajzen, Attitudes, Personality, and Behavior, 2nd ed., Maidenhead: Open University Press, 2005.

[43] M. Alkailani, I. A. Azzam, and A. B. Athamneh, "Replicating hofstede in Jordan: Ungeneralized, reevaluating the Jordanian culture,' International Business Research, vol. 5, no. 4, pp. 71-80, 2012.
[44] M. Fishbein and I. Ajzen, Belief, Attitude, Intention and Behavior: An Introduction to Theory and Research, Reading, Mass.: Addison-Wesley Pub. Co., 1975.

[45] I. Ajzen, "Theory of planned behavior," Handbook of Theories of Social Psychology, vol. I, pp. 438-460, Los Angeles: SAGE, 2012.

[46] A. Scarino, Teaching and Learning Languages: A guide, Carlton South, Vic: Curriculum Corporation, 2009.

[47] R. K. Hopson, "Reclaiming knowledge at the margins: Culturally responsive evaluaiton in the current evaluation moment," The SAGE International Handbook of Educational Evaluation, K. E. Ryan and J. B. Cousins, eds., pp. 429-447, Thousand Oaks: SAGE, 2009.

[48] J. W. Creswell, Designing and Conducting Mixed Methods Research, 2nd ed., Los Angeles: SAGE Publications, 2011.

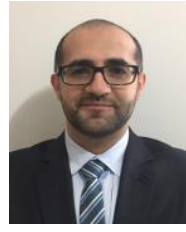

Marwan Albahri is a lecturer at the English Department, School of Arts at Hail University in Saudi Arabia Currently, he is a $\mathrm{PhD}$ student in applied linguistics at the School of Humanities and Communication Arts at the Western Sydney University. His research investigates Saudi tertiary teachers' and learners' attitudes towards the communicative language teaching: A mixed method

approach.

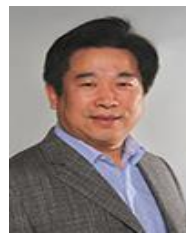

Ping Yang received a $\mathrm{PhD}$ in linguistics from Macquarie University, Australia. He is a senior lecturer in linguistics and an academic course advisor for master of arts in TESOL in the School of Humanities and Communication Arts at Western Sydney University. His research interests cover. intercultural communication, intercultura nonverbal communication, English-Chinese translation, and teacher training in teaching English to speakers of other languages (TESOL). He has published extensively in these areas and supervises $\mathrm{PhD}$ candidates conducting their projects in the similar field.

Dr. Mohamed Moustakim is a senior lecturer in education in the master of teaching primary, School of Education, Western Sydney University. Hi main research interests are broadly focused on equity and diversity in Education. He is an experienced researcher and currently supervises 8 Higher Degree Research students. Mohamed qualified as a secondary school teacher at the 'Centre Pedagogique Regional' in Casablanca and taught in Morocco in the early $80 \mathrm{~s}$. He gained a postgraduate Diploma in Youth and Community Studies at the University of Greenwich, where he subsequently completed an MA in Education. He also completed the Graduate Diploma in Psychology at the University of Westminster and a Doctorate in Education at the University of Exeter. Prior to joining Western Sydney, Mohamed taught in undergraduate and postgraduate programs in Education and Youth Studies at several universities in the UK since late 90 s. 